\title{
Key determinants of students' mobile phone choice
}

\author{
Michael Dzigbordi Dzandu ${ }^{a}$ Henry Boateng ${ }^{b^{*}}$ and Cynthia Esinu Dzandu ${ }^{b}$
}

${ }^{a}$ Department of Information Studies, University of Ghana, Ghana

${ }^{b}$ Department of Marketing and Customer Management, University of Ghana Business School, Ghana

\section{H R O N I C L E}

\section{Article history:}

Received January 28, 2014

Received in revised format

5 May 2014

Accepted 2 July 2014

Available online

July 12014

Keywords:

Mobile phones

Brand choice

Quality

Students

University

ICT

Ghana

\section{A B S T R A C T}

As there is still only limited research on students brand choice of mobile phones, the focus of this study was to ascertain drivers of tertiary students' mobile phone brand choice in Ghana. Using a structured questionnaire, data was collected from a random sample of 840 students from three tertiary institutions in Ghana. The study revealed that the most significant determinant of the students brand choice of mobile phones was perceived quality $(p<0.05)$. Although price, prestige, and promotion also influenced their choice of mobile phone these were not significant at the 0.05 level. The study further revealed that availability and mobile phones as gift items also influenced the brand of phone used by the students $(\mathrm{p}>0.05)$. The study concludes that in spite of their economic handicaps, students brand choice was driven most by perceived quality and not price. Recommendations on how information technology manufacturers' particularly mobile phone companies and marketers can exploit these drivers to sustain and improve their brand equity among students have been made.

\section{Introduction}

As the hi-tech industry grows and the facet of hi-tech products becomes almost the same, it is highly difficult for consumers to distinguish between brands based on their cogent attributes alone (Temporal \& Lee, 2001). Consumers are always exposed to brands of mobile phones in the course of everyday because of marketing activities and as an upshot of their daily encounters with others (Ferraro et al., 2009). The consumer now chooses from among brands in a market that is encumbered with different promotional activities, price information and other socio-economic pointers. Therefore mobile phone producing companies must build strong brands in order to win consumer preferences, loyalty and build a long lasting relationship with them (Kay, 2006). Branding permeates almost every aspect of economic activity; both in business and consumer markets (Keller, 2008). 
Many companies develop marketing strategies in order to improve their sales and to make their brands stand out among competitive ones (Narteh et al., 2012). Keller (2008) mentioned that successful brands instill trust in consumers and define a set of positive expectations in the consumers' minds. Walker (2008) contends that people are embracing brands more than ever before - creating brands of their own and participating in marketing campaigns for their favourite brands in unprecedented ways. Unlike consumables, brands in the high-technology industry do not concentrate on the association between products and companies but rather with the brand image (Hamann et al., 2007). The mobile phone market has been noted as one of the most unstable market environments today due to the competition mobile phone brands present (Karjaluoto et al., 2005).

It is therefore necessary to cast light on the factors that finally determine students' choices between different mobile phone brands (Riquelme, 2001). It appears studies investigating consumer brand choice of mobile phones have produced inconsistent results and have mainly been conducted in the Asian world (Hao, et al., 2007, Liu, 2002; Marat, 2009) and Europe (Karjaluoto et al., 2005; Petruzzellis, 2010; Yaşa \& Bozyiğit, 2012). However, the socio-economic variables of these regions differ from that of Ghana. A few studies on mobile phone brands in Ghanaian context focused on the mobile telecommunication network brand preferences among subscribers in Cape Coast and Accra (Dadzie \& Boachie-Mensah, 2001; Boateng \& Quansah, 2013). This study therefore attempts to fill the gap in extant literature on key determinants of mobile phone choices among students who are largely the youth and the most active users of mobile phones. The purpose of this paper therefore, is to ascertain the factors influencing Ghanaian students' brand choice of mobile phones. The rest of the paper is divided into three sections; section one focuses on literature review and conceptual framework whilst section two focuses on methodology. The study concludes with discussion of findings, conclusion and recommendations.

\section{Branding and Mobile Phone Brands Choice}

Branding has existed for ages (Keller, 2008). It was used in the olden days to distinguish one flock from the other (Bertilsson, 2009). Branding enables consumers to identify and distinguish one product from the other (Bertilsson, 2009). The American Marketing Association (AMA) (2003) defines branding as "name, term, sign, symbol or design or a combination of them, intended to identify the goods and services of one seller or group of sellers and differentiate them from those of their competitors". Keller (2008) asserts that branding is more than this- it creates awareness, prominence, and reputation etc in the 'competitive arena' of companies.

Chan and Huang (1997) mention that effective branding will actually make the choice for consumers regarding what to buy. A successful brand has a recognizable name which signals specific attributes to the consumer (Narteh et al., 2012). Farquhar (1989) notes that building a strong brand within consumers' minds means creating a positive brand assessment, an open brand attitude, and a dependable brand image; the open brand attitude actually referring to what the others term as awareness. A successful brand is an identifiable product, service, person or place 'dressed' in such a way that the buyer or user notices relevant, distinctive added values which match their needs most closely (De Chernatony \& McDonald, 1998).

Hood and Henderson (2005) have further highlighted 12 fibers of elucidation from the branding literature: Legal instrument, Logo, Company, Shorthand, Risk reducer, Identity system, Image in consumer mind, Value system, Personality, Relationship, Adding value, and Evolving entity. Advances in information and communication technologies are frequently impacting on the way people use and experience technology, which is ever more invasive in consumers' life (Petruzzellis, 2010). In a study by Petruzzellis (2010) on mobile phone choice: technology versus marketing: brand effect in the Italian market, he noted that brand attitudes have positive impact on consumer intention to purchase specific mobile phones over others. He therefore concluded that, the success of mobile 
phone choice is not only a function of technological characteristics but also depends on individuals and many social dynamics.

Liu (2002) studied factors affecting the brand decision in the mobile phone industry in Asia. It was noted that the choice of a cellular phone is characterized by two discrete attitudes toward brands: attitudes towards the mobile phone brand on one hand and attitudes towards the network on the other. Price and regularity of service were also found to impact on choices between network providers, and choices between mobile phone. The study also found that consumer brand choice was affected by new technology features such as memory capacity and SMS-options. Other findings on consumer brand choice include perceived quality (Sethuraman \& Cole, 1999), promotion (Steyn \& Puth, 2000), price and prestige (Liu, 2002), and emotional connection (Gobe, 2001).

\section{Key Determinants of Mobile Phone Choice}

There are several factors that drive consumers' choice of a brand in a given situation. Over the years scholars have investigated factors that influence consumers' choice of brands. Various factors have been identified. These factors include perceived quality (Sethuraman \& Cole, 1999), promotion (Steyn \& Puth, 2000) price and prestige (Liu, 2002), and emotional connection (Gobé, 2001).

\subsection{Perceived Quality}

This is the perception of customers of the product's quality in its totality as compared to other competitive brands and with respect to its intended purposes (Keller, 2008). According to Garvin (1987) perceived quality of a brand can be summarized into eight dimensions: durability, features, aesthetics, serviceability, reliability, performance, conformance, and perceived quality. These factors define quality of brand and in turn drive a consumer's attitude and behaviour towards that brand (Keller, 2008). Vanrenen (2005) asserted that brand credibility and perceived value are very essential elements marketers need to pursue to build a strong brand.

Aaker (1991) stated that consumer evaluations of brands increase if the brand is perceived to be of good quality. Erdem and Swait (1998) also suggest that brand credibility increases perceived quality, decreases perceived risk and information costs, and consequently increases consumer's brand purchase intention. Soomro et al. (2011) studied factors influencing brand choice and noted packaging as a reason to purchase a brand. It was considered as first reason by $15.7 \%$ of the respondents, $12.3 \%$ as second reason, and $21.6 \%$ as third reason to buy a brand. Farquhar et al. (1992) conclude that in order for a firm to leverage on its brand, it is important that the core feature is identified. This may range from the brand's core functions, added features (Keller, 2008) or benefits derived from the brand (Liu, 2002). Jones (2002) mentions that consumer's value in elegant phones features enhance their personal time planning. A report by In-Stat/MDR (2002) indicated that colour displays are now driving consumers into stores to purchase new mobile phones and related devices such as PDAs.

\section{$H_{1:}$ Perceived quality influence Ghanaian students choice of mobile phone brands.}

\subsection{Promotion}

Promotion is a form of corporate communication that uses various strategies to disseminate specific information about an organization and its products to a targeted audience. It strengthens the brand node in memory that makes it easy for the consumer to remember the brand (Keller, 1993). Brand awareness is argued as the crucial first stage of buyer readiness (Steyn \& Puth, 2000). Some scholars have also seen brand awareness as an element that plays a vital role in consumer's choice of brand (Keller, 2008). Hoyer and Brown (1990) examined the importance of brand awareness in consumers' 
decision making process and they found out that brand awareness was a primary factor. Jiang (2004) also noted that brand recognition influences consumer's choice. A consumer is more likely to choose a product with higher brand awareness, regardless of quality and price (Macdonald \& Sharp, 2000). According to Keller (1993), customer awareness and association influences inferred attributes, perceived quality and finally result in brand loyalty. Brand attitude can only be established when brand awareness has occurred and intention to buy has been proven (Rossiter \& Percy, 1987; Rossiter et al., 1991). A study by Hoyer and Brown (1990) showed that over $70 \%$ of consumers surveyed choose known brand of peanut butter from among a choice of three, even though another brand was arguably of better quality than that. Ayanwale et al. (2005) studied the influence of advertising on consumer brand preference for Bournvita in Nigeria and found that both male and female of different age groups were equally influenced by advertising in their preference for the brand. They therefore concluded that companies that want to retain their market and increase their market share must not underrate advertising.

\section{$\mathrm{H}_{2}$ : Promotions influence Ghanaian students' choice of mobile phone brands}

\subsection{Prestige}

In today's marketplace, consumers often decide to purchase certain items based on the brand's image than on its physical features (Graeff, 1996). A brand may symbolize a consumers' status in society and this influence the kind of brand they select (Keller, 2008). Lassar et al. (1995) found that brand with high brand image always have higher brand equity and premium price. Keller (2008) asserted that how a brand is positioned in the minds of a group of customers or market segment influence them to think of the brand in the desired way. Pitta and Katsanis (1995) also stated that a distinctive, satisfactory and resilient brand image allows the brand to be easily differentiated and positioned in the clients mind, thereby adding to the prospects of improved brand equity.

Kotler et al. (1999) noted that apart from cultural factors, other factors such as social status influence what a consumer buys. Hoyer and Brown (1990) also provide empirical evidence for prestige being a driver in consumer brand choice. Also findings by Liu (2002) show prestige to be the highest contribution to consumers brand choice of mobile phones. It is therefore not surprising to see that the consumer market has recently seen a substantial amount of luxury brand marketing (Wiedmann et al., 2009). Datte'e and Weil (2005) have also noted social diversities as the key determinants shaping the interactions between the perception of technological evolution and the formation of expectations by consumers.

\section{$H_{3:}$ Prestige influences Ghanaian students' choice of mobile phone brands.}

\subsection{Price}

Scholars have long noted that consumers are more sensitive to price in the choice of a product (Bitta \& Monroe 1974). However, loyal customers are insensitive to price changes of their preferred brand (Krishnamurthi \& Raj 1991). Nowlis and Simonson (2000) got empirical evidences that price affects consumer choice of service, whilst Bateson (1995), and Gabbott and Hogg (1999), also agreed to this from a theoretical point of view.

Generally, consumers are willing to pay higher prices for brands that they perceive to have high value (Erdem \& Swait, 1998) as the brand reflects the product's quality. According to Söderlund (2006), price, place and brand are three important factors when deciding consumers purchase choice in everyday product. In addition, customers have a strong belief in the price and value of their favourite brands so much so that they would compare and evaluate prices with alternative brands (Keller, 2003). 


\section{$H_{4:}$ Price influences Ghanaian students' choice of mobile phone brands.}

\section{Methodology}

This study employed the survey research design. This research design was chosen because it provided a basis for generalization of the findings from the sample to the population. Again, it made it possible for inferences to be made about students' attitude and behaviour towards the choice of mobile phone (Babbie, 1990). The respondents were made up of 481 (59.6\%) students from a Public University, 155 (18.5\%) from a Private University and 204 (24.3\%) from a Polytechnic which gives this study diversity in the sample as compared to Hao, et al., 2007 who used data from only one University in a similar study. The student population was chosen for this study because they represent a user group that is fascinated about mobile phones (Hakoama \& Hakoyama, 2011).

Additionally, they were chosen because they are a microcosm of youth and possess similar demographic and socio-economic characteristics. Furthermore, they share a relatively common base of experience in terms of mobile phones selection (Mokhlis and Yaakop, 2012). In all 840 subjects participated in the study. This is justified because some studies (Hao, et al., 2007; Dadzie \& BoachieMensah, 2011; Boateng \& Quansah, 2013; Narteh et al., 2012) have used samples less than this. The respondents were made up of $340(40.5 \%)$ females and $500(59.5 \%)$ males. The students were aged between 16years and 50years with a median age of 23years, modal age of 22 years and an average age of 25.4 years. They were made up of $740(89.2 \%)$ undergraduate and $90(10.8 \%)$ postgraduate students from four major faculties namely Arts (8.1\%), Social Studies (41.6\%), Business (27.5\%) and Science $(22.8 \%)$. Copies of the questionnaire based on the study's objectives were distributed to each subject in the sample. The constructs were derived from the extant literature. Descriptive statistics was used to presents the results of the study. The chi-square test of independence was used to ascertain the significance of the relationship between the independent and the dependent variables at the $95 \%$ significance level.

\section{Results and Discussion}

The results have been presented under two key themes; type and brand of mobile phones and drivers of mobile phone brand choice. These are followed by a discussion of the findings.

\subsection{Type and Brand of Mobile Phones}

The entire respondents owned and use mobile phones. Interestingly, even though the majority $(65.1 \%)$ of the students had only one mobile phone, quite a number of the students owned multiple phones. The data for the study showed that 252 (30.5\%) students had two mobile phones and the remaining $37(4.5 \%)$ had three, four and as many as seven mobile phones. Clearly, there is evidence to suggest that Ghanaian tertiary students owned multiple phones perhaps due to the strong desire to always stay in touch with people even when their active mobile phone is faulty or lost.

The type of mobile phones owned by the students were mainly single SIM (74.1\%) even though a few of them had dual SIM (22.2\%) and triple SIM (1.1\%) phones. The data for the study revealed that the top brand was Nokia (44.4\%) similar to the findings of Yaşa and Bozyiğit, (2012) who reported an even higher (54.3\%) preference for the Nokia brand among University students in Turkey. The other top brands from this study were Samsung (11.1\%), Techno (6.3\%), Sony (4.6\%), and LG (4.5\%). In addition to these, $13.7 \%$ of the students owned multiple brands whilst a few, 9 $(1.1 \%)$ of them had network branded mobile phones from some of the mobile phone service providers namely MTN and Airtel. It was noted that the respondents had been using mobile phones for as long as 20 years and as recent as 3 weeks. The majority of the students have been using mobile phones for 
1-5years (47.6\%) and 6-10years (42.9\%). But generally, the students had been using mobile phones for a considerable number of years.

\subsection{Drivers of Students Mobile Phone Brand}

Data for the study revealed six instead of the four key determinants of the student's mobile phone brand choice. These were perceived quality $(86.4 \%)$, price $(5.8 \%)$, prestige $(2.3 \%)$ and promotion $(1.2 \%)$. In addition to these four major drivers identified from extant literature, the study also uncovered availability (2.1\%) and gift $(1.9 \%)$ as drivers of the mobile phone brand choice of the students (Table 1). Further analysis using, the chi-square test of goodness of fit, revealed that, at the 0.05 level, perceived quality significantly influenced the students brand choice of mobile phone $\left(X^{2}=2554.8, \mathrm{df}=5, \mathrm{p}<0.05\right)$ than any other factor.

\section{Table 1}

Drivers of students brand choice of mobile phones

\begin{tabular}{lcc}
\hline Drivers of brand choice & Frequency & Percent \\
\hline Perceived quality & 629 & 86.4 \\
Promotion & 9 & 1.2 \\
Price & 43 & 5.9 \\
Prestige & 17 & 2.3 \\
Availability & 16 & 2.2 \\
Gift & 14 & 1.9 \\
\hline Total & 728 & 100.0 \\
\hline$\left(X^{2}=2554.8, \mathrm{df}=5, \mathrm{p}<0.05\right)$ & &
\end{tabular}

In addition, among the eight dimensions of quality, durability $(40.2 \%)$ was the dominant factor that influenced the perceived quality ratings of the students $\left(X^{2}=543.0, \mathrm{df}=7, \mathrm{p}<0.05\right)$. This was followed by features $(15.3 \%)$ and perceived quality $(14.7 \%)$, aesthetics $(11.0 \%)$, reliability $(10.7 \%)$, serviceability $(4.8 \%)$, performance $(3.0 \%)$ and conformance $(0.3 \%)$.

The researchers tested for the significance (if any) of the relationship between the mobile phone brands and the key determinants of the students brand choice of mobile phones. The significance of the relationship between these drivers and some personal characteristics and choices of the students namely gender, age, number of phones owned type of phone, programme of study and level in the university, network service provider and Internet usage were also examined. The results in Table 2 show the drivers of the students brand choice of mobile phones as against the brands of phone they were using.

Table 2

Drivers of Tertiary Students Mobile Phone Brand Choice

\begin{tabular}{lccccccc}
\hline Brand & & \multicolumn{3}{c}{ Drivers of mobile phone brand choice } & & & \\
& Perceived quality & Promotion & Price & Prestige & Availability & Gift & Total \\
\hline Nokia & 306 & 5 & 9 & $11(64.7 \%)$ & 5 & 3 & 339 \\
& $(48.6 \%)$ & $(55.6 \%)$ & $(20.9 \%)$ & $11(31.2 \%)$ & $(21.4 \%)$ & $(46.6 \%)$ \\
Samsung & $70(11.1 \%)$ & - & $2(4.7 \%)$ & $1(5.9 \%)$ & $2(12.5 \%)$ & $4(28.6 \%)$ & $79(10.9 \%)$ \\
Tecno & $34(5.4 \%)$ & - & $9(20.9 \%)$ & $2(11.8 \%)$ & $1(6.2 \%)$ & - & $46(6.3 \%)$ \\
Sony & $29(4.6 \%)$ & $1(11.1 \%)$ & - & - & $2(12.5 \%)$ & - & $32(4.4 \%)$ \\
LG & $23(3.7 \%)$ & $1(11.1 \%)$ & $2(4.7 \%)$ & - & - & $2(14.3 \%)$ & $28(3.8 \%)$ \\
Other brands & $80(12.7 \%)$ & $1(11.1 \%)$ & $18(41.9 \%)$ & $1(5.9 \%)$ & $2(12.5 \%)$ & $2(14.3 \%)$ & $104(14.3 \%)$ \\
Multiple & $87(13.8 \%)$ & $1(11.1 \%)$ & $3(7.0 \%)$ & $2(11.8 \%)$ & $4(25.0 \%)$ & $3(21.4 \%)$ & $100(13.7 \%)$ \\
brands & $629(100 \%)$ & $9(100 \%)$ & $43(100 \%)$ & $17(100 \%)$ & $16(100 \%)$ & $14(100 \%)$ & $728(100 \%)$ \\
\hline Total & & & & &
\end{tabular}

It was observed that the brand of mobile phones used by the students were significantly tied to the drivers of brand choice $\left(X^{2}=77.1, \mathrm{df}=390 \mathrm{p}<0.05\right)$. It can be observed that the students' choice of the Nokia brand of mobile phone was significantly influenced by prestige $(64.7 \%)$, promotion $(55.6 \%)$ 
and perceived quality (48.6\%). The choice of other brands of phones was found to be significantly dependent on the price (41.9\%) whilst the choice of multiple mobile phone brands was influenced significantly by availability $(25.0 \%)$. Also, the choice of the Samsung brand of mobile phone was significantly influenced by gift (28.6\%). Therefore the hypotheses that perceived quality, price, promotion and prestige would influence the mobile phone brand choice of Ghanaian students were supported. In addition, the data for the study also revealed that availability of a brand and mobile phones as gift items significantly determined the brand of mobile phones used by the students.

Further analysis of the data for the study revealed that the gender, level of the student, type of mobile phone, type of network subscribed to as well as the need to access the Internet by the students significantly influenced the mobile phone brand choice of the students. The relationship between the gender and drivers of the mobile phone brand choice of the students was significant $\left(X^{2}=19.9, \mathrm{df}=5\right.$, $\mathrm{p}<0.05$ ) at the 0.05 level (Table 3 ).

Table 3

Drivers of mobile phone brand choice by gender

\begin{tabular}{lccccccc}
\hline \multirow{2}{*}{ Gender } & & \multicolumn{3}{c}{ Drivers of brand choice } & & \\
& Perceived quality & Promotion & Price & Prestige & Availability & Gift & Total \\
\hline Male & $368(58.5 \%)$ & $7(77.8 \%)$ & $37(86.0 \%)$ & $8(47.1 \%)$ & $6(37.5 \%)$ & $6(42.9 \%)$ & $432(59.3 \%)$ \\
Female & $261(41.5 \%)$ & $2(22.2 \%)$ & $6(14.0 \%)$ & $9(52.9 \%)$ & $10(62.5 \%)$ & $8(57.1 \%)$ & $296(40.7 \%)$ \\
Total & $629(100 \%)$ & $9(100 \%)$ & $43(100 \%)$ & $17(100 \%)$ & $16(100 \%)$ & $14(100 \%)$ & $728(100 \%)$ \\
\hline$\left(X^{2}=19.9, \mathrm{df}=5, \mathrm{p}<0.05\right)$ & & & & &
\end{tabular}

It was observed that for the male students, their choice of mobile phone brand was significantly influenced by price $(86.0 \%)$, promotion $(77.8 \%)$ and perceived quality $(58.5 \%)$ whilst the female students were most influenced by availability $(62.5 \%)$, gift $(57.1 \%)$ and prestige $(52.9 \%)$ of the mobile phone.

The level of the students (freshmen, continuing, or postgraduate) significantly influenced their choice of mobile phone brand $\left(X^{2}=46.5, \mathrm{df}=20, \mathrm{p}<0.05\right)$ (Table 4$)$.

\section{Table 4}

Drivers of mobile phone brand choice by level

\begin{tabular}{|c|c|c|c|c|c|c|c|}
\hline \multirow{2}{*}{ Level } & \multicolumn{6}{|c|}{ Drivers of brand choice } & \multirow[b]{2}{*}{ Total } \\
\hline & $\begin{array}{l}\text { Perceived } \\
\text { quality }\end{array}$ & Promotion & Price & Prestige & Availability & Gift & \\
\hline 100(Freshmen) & $187(30.0 \%)$ & $3(33.3 \%)$ & $5(11.9 \%)$ & $3(17.6 \%)$ & $2(12.5 \%)$ & $2(14.3 \%)$ & $\begin{array}{c}202 \\
(28.0 \%)\end{array}$ \\
\hline $200(*)$ & $136(21.8 \%)$ & $1(11.1 \%)$ & $9(21.4 \%)$ & - & $5(31.2 \%)$ & $4(28.6 \%)$ & $\begin{array}{c}155 \\
(21.5 \%)\end{array}$ \\
\hline $300(*)$ & $141(22.6 \%)$ & $3(33.3 \%)$ & $9(21.4 \%)$ & $9(52.9 \%)$ & $6(37.5 \%)$ & $6(42.9 \%)$ & $\begin{array}{c}174 \\
(24.1 \%)\end{array}$ \\
\hline $400(*)$ & $99(15.9 \%)$ & $2(22.2 \%)$ & $6(14.3 \%)$ & $1(5.9 \%)$ & $2(12.5 \%)$ & $2(14.3 \%)$ & $\begin{array}{c}112 \\
(15.5 \%)\end{array}$ \\
\hline 600 (Postgrad) & $60(9.6 \%)$ & - & $13(31.0 \%)$ & $4(23.5 \%)$ & $1(6.2 \%)$ & - & $78(10.8 \%)$ \\
\hline Total & $623(100 \%)$ & $9(100 \%)$ & $42(100 \%)$ & $17(100 \%)$ & $16(100 \%)$ & $14(100 \%)$ & $721(100 \%)$ \\
\hline
\end{tabular}

It was observed that the freshmen (Level 100) were influenced most by perceived quality (30.0\%) and promotions $(33.3 \%)$ in choosing their brand of mobile phones whilst the postgraduate (Level 600 ) students placed much emphasis on the price (31.0\%). The continuing students were swayed by a combination of promotion (33.3\%), availability $(37.5 \%)$, gift $(42.9 \%)$ and prestige $(52.9 \%)$ in choosing the brand of mobile phones they were using. 
The results showed that those students who owned single SIM phones were influenced by perceived quality $(75.9 \%)$, promotion $(77.8 \%)$, prestige $(88.2 \%)$, availability $(81.2 \%)$ and gifts $(92.3 \%)$ in choosing their brand of mobile phones (Table 5). On the other hand, those students who owned multiple SIM phones were influenced mostly by price (65.9\%) in choosing those phones

Table 5

Drivers of mobile phone brand choice by type of phone

\begin{tabular}{lccccccc}
\hline $\begin{array}{l}\text { Type of Phone } \\
\text { (SIM) }\end{array}$ & $\begin{array}{c}\text { Perceived } \\
\text { quality }\end{array}$ & Promotion & Price & Prestige & Availability & Gift & Total \\
\hline Single SIM & $472(75.9 \%)$ & $7(77.8 \%)$ & $14(34.1 \%)$ & $15(88.2 \%)$ & $13(81.2 \%)$ & $12(92.3 \%)$ & $533(74.2 \%)$ \\
Multiple SIM & $150(24.1 \%)$ & $2(22.2 \%)$ & $27(65.9 \%)$ & $2(11.8 \%)$ & $3(18.8 \%)$ & $1(7.7 \%)$ & $185(25.8 \%)$ \\
\hline Total & $622(100 \%)$ & $9(100 \%)$ & $41(100 \%)$ & $17(100 \%)$ & $16(100 \%)$ & $13(100 \%)$ & $718(100 \%)$ \\
\hline$\left(X^{2}=39.8, \mathrm{df}=5, \mathrm{p}<0.05\right)$ & & & & & &
\end{tabular}

Thus, the type of mobile phone owned by the students was significantly influenced by the drivers of brand choice $\left(X^{2}=39.8, \mathrm{df}=5, \mathrm{p}<0.05\right)$.

Data for the study showed that the type of network service provider the students subscribed to influenced their choice of mobile phone brand. It was found that most of the students who subscribed to the MTN network were significantly influenced by the quality $(51.7 \%)$, price $(51.2 \%)$ and the prestige $(50.0 \%)$ of the mobile phones in choosing the brand of phones they were using (Table 6).

\section{Table 6}

Drivers of mobile phone brand by type of network used

\begin{tabular}{|c|c|c|c|c|c|c|c|}
\hline \multirow{2}{*}{$\begin{array}{l}\text { Type of } \\
\text { network }\end{array}$} & \multirow[b]{2}{*}{$\begin{array}{c}\text { Perceived } \\
\text { quality }\end{array}$} & \multicolumn{5}{|c|}{ Drivers of brand choice } & \multirow[b]{2}{*}{ Total } \\
\hline & & Promotion & Price & Prestige & Availability & Gift & \\
\hline Expresso & $3(0.5 \%)$ & $1(12.5 \%)$ & $1(2.4 \%)$ & - & - & - & $5(0.7 \%)$ \\
\hline Tigo & $43(7.1 \%)$ & $1(12.5 \%)$ & $1(2.4 \%)$ & - & - & $1(7.7 \%)$ & $46(6.6 \%)$ \\
\hline MTN & $312(51.7 \%)$ & $2(25.0 \%)$ & $21(51.2 \%)$ & $8(50.0 \%)$ & $5(33.3 \%)$ & $6(46.2 \%)$ & $354(50.8 \%)$ \\
\hline Vodafone & $38(6.3 \%)$ & $3(37.5 \%)$ & $2(4.9 \%)$ & $2(12.5 \%)$ & $2(13.3 \%)$ & - & $47(6.7 \%)$ \\
\hline Airtel & $45(7.5 \%)$ & - & - & $1(6.2 \%)$ & $2(13.3 \%)$ & $1(7.7 \%)$ & $49(7.0 \%)$ \\
\hline $\begin{array}{l}\text { Multiple } \\
\text { networks }\end{array}$ & $163(27.0 \%)$ & $1(12.5 \%)$ & $16(39.0 \%)$ & $5(31.2 \%)$ & $6(40.0 \%)$ & $5(38.5 \%)$ & $196(28.1 \%)$ \\
\hline Total & $604(100 \%)$ & $8(100 \%)$ & $41(100 \%)$ & $16(100 \%)$ & $15(100 \%)$ & $13(100 \%)$ & $697(100 \%)$ \\
\hline
\end{tabular}

The relationship between the type of telecommunications network used by the students and their brand choice of mobile phones was significant at the 0.05 level.

The study also revealed that the need to use mobile phone for Internet access influenced the mobile phone brand choice of the students $\left(X^{2}=20.9, \mathrm{df}=5, \mathrm{p}<0.05\right)$.

The majority of the students, who need to use their mobile phones for Internet access, were influenced by almost all the drivers from perceived quality $(79.2 \%)$ of mobile phones that support Internet access, to the availability (68.8\%) of Internet ready mobile phones. Generally, most of the background characteristics of the students significantly influenced their mobile phone brand choice at the 0.05 level. 
Table 7

Drivers of mobile phone brand by use of phone for Internet access

\begin{tabular}{lccccccc}
\hline $\begin{array}{l}\text { Use of phone for } \\
\text { Internet access }\end{array}$ & $\begin{array}{c}\text { Perceived } \\
\text { quality }\end{array}$ & Promotion & Price & Prestige & Availability & Gift & Total \\
\hline Yes & $483(79.2 \%)$ & $4(50.0 \%)$ & $21(51.2 \%)$ & $13(76.5 \%)$ & $11(68.8 \%)$ & $11(78.6 \%)$ & $543(76.9 \%)$ \\
No & $127(20.8 \%)$ & $4(50.0 \%)$ & $20(48.8 \%)$ & $4(23.5 \%)$ & $5(31.2 \%)$ & $3(21.4 \%)$ & $163(23.1 \%)$ \\
\hline Total & $610(100.0 \%)$ & $8(100.0 \%)$ & $41(100.0 \%)$ & $17100.0 \%)$ & $16(100.0 \%)$ & 14 & $\begin{array}{c}706 \\
\end{array}$ \\
\hline
\end{tabular}

$\left(X^{2}=20.9, \mathrm{df}=5, \mathrm{p}<0.05\right)$

The study, however, revealed that, there was no significant relationship between the age of the students and their mobile phone brand choices $\left(X^{2}=24.3, \mathrm{df}=15, \mathrm{p}>0.05\right)$. This was probably due to the fact that the subjects were tertiary students and possessed similar age characteristics. Also, the drivers of the mobile phone brand choice of the students were not significantly dependent on the number of mobile phones owned by students $\left(X^{2}=2.6, \mathrm{df}=5, \mathrm{p}>0.05, \mathrm{p}>0.05\right)$, number of years the students have been using mobile phones $\left(X^{2}=12.6, \mathrm{df}=10, \mathrm{p}>0.05, \mathrm{p}>0.05\right)$, or their faculty or program of study $\left(X^{2}=18.6, \mathrm{df}=15, \mathrm{p}>0.05\right)$ and also the type of institution (private or public university or polytechnic) they belonged to $\left(X^{2}=16.7, \mathrm{df}=10, \mathrm{p}>0.05\right)$.

\section{Discussion of Results}

Quality is an unparalleled factor in product development and service delivery. It has several dimensions notably performance, reliability, features, durability, performance among others (Garvin, 1987). Manufacturers and marketers have always had to choose among a mix of factors for their products/services development at particular times (Keller, 2008). For ICT products, like mobile phones, computers, storage devices and many others, prices are arguably decreasing whilst the availability of cheap synthetic raw materials have compromised the quality. Nonetheless, the study revealed that the Ghanaian tertiary students mobile phone brand choice was significantly, influenced by perceived quality than any other factor. Quality is a key determinant of the students' choice of mobile phones. They choose phones that can last longer and have many applications. The findings of Keller (2008), Vanrenen (2005) and Aaker (1991) were thus supported by this study as perceived quality accounted for $86.7 \%$ of the responses on drivers of mobile phone brands. Garvin's (1987) eight dimensions of quality were evident in the study as durability significantly influenced the perceived quality ratings of the students' brand choice of mobile phone.

Promotion as a driver of brand choice has been largely documented. However, promotion did not significantly affect the mobile phone brand choices of the students. The study revealed that promotion accounted for only $1.2 \%$ of the responses on the drivers of brand choice as compared to $70.0 \%$ reported by Hayer and Brown (1990). In this study, promotion ranked as the $4^{\text {th }}$ influential factor in the mobile phone brand choice of the Ghanaian tertiary student. Thus, Keller's (1993), Steyn and Puth (2000) and Brown's (1990) report that brand awareness through promotion was a primary factor in brand product choices was not evident from the data on tertiary students in Ghana. This is not surprising, as advertisements on mobile phone brand appear not to have been very strong on the Ghanaian market. Contrary to Macdonald and Sharp's (2000) findings that regardless of quality and price, promotion mostly influences customers decision, perceived quality rather than any other factor significantly influenced the mobile phone brand choice of the Ghanaian tertiary students.

Prestige is known to influence brand equity and price (Lassar et al., 1995) and purchase other than aesthetic features (Graeff, 1996). However, the study found that prestige accounted for only (2.3\%) of the responses on drivers of students mobile phone brand choices and was the third ranked factor influencing the brand decisions of the students. This contradicts Lui's (2002) findings that prestige 
was the highest contribution to consumers brand choice of mobile phones. Prestige although contributes students' choice of mobile phone brands, it was not the key factor. It is possible that because the sample was limited to students and most of them bought or have been using mobile phones for some time, probably the phones they were using were actually not the brand of phone they would have bought if they had the means. Probably, most of the students would have bought the latest smart phones and i-phones for the sake of prestige, if these were indeed available and also if they could afford. The study, however, did not enquire from the respondents what brand of phone they would have bought or would like to have. This would have been more indicative of the influence of prestige as a determinant of the mobile phone brand choice of the students.

The existing literature has identified price as a significant factor in mobile phone brand choice among students (Bitta \& Monroe, 1974; Doob et al, 1996; Nowlis \& Simonson, 2000; Bateson, 1995; Gabbot \& Hogg, 1998). On the contrary, the study found that price was the $2^{\text {nd }}$ influencing factor in the mobile phone brand choice of the students and accounted for only $5.6 \%$ of the responses on the Ghanaian tertiary students' mobile phone brand choice. It is averred that probably price was not a significant factor because most tertiary students are dependent on their parents for financial support and did not had very tight budget for personal items like mobile phones. In effect, they might have considered a quality phone that will last longer over a cheap phone which may need to be replaced over short periods. Thus, even though price affected brand choice of mobile phones among Ghanaian tertiary students, this was not significant at the 0.05 level. This indicates that, if the brand is of good quality, manufacturers can charge a premium price and the students would still have bought those brands of mobile phones.

Availability (Dadzie \& Boachie-Mensah, 2011) and gifts (1.9\%) also influenced the mobile phone brand choice of the students but these were not significant at the 0.05 level. These indicate that if manufacturers flood the mobile phone market with their brands, they may influence the Ghanaian tertiary students into buying their brands. Occasions like Valentine's Day, Christmas and Easter may as well be opportunities for mobile phone dealers to package or bundle mobile phone products, may be with network providers, and offer the packages as unique/ideal gifts for people to purchase for their friends and loved ones. Such strategic alliances may inure to the benefit of both the manufacturers, retailers and mobile phone network service providers.

Most of the personal characteristics of the students namely the gender of the students, the number of years they have been using mobile phones, their need to use mobile phone for Internet access, and the network service providers they subscribed to significantly influenced their choice of mobile phone brand. Also, the mobile phone brand choice of the students was significantly dependent on the type of phone used by the students (single or multiple SIM), as well as the level of the students (freshmen, continuing or postgraduate). These clearly support the findings of Ayanwale et al. (2005), Kotler et al. (1999), Datte'e and Weil (2005) who have also reported significant relationship between the personal or social characteristics of consumers and their brand choices.

\section{Conclusions and Recommendations}

The study established that tertiary student's mobile phone brand choice is significantly influenced by perceived quality than any other consideration. Interestingly, the study uncovered gift as a determinant of the students brand choice in that their choice of mobile phone was as a result of a gift they received from friends, relation or loved ones. In addition, the study uncovered over 30 brands of mobile phones being used by the students. This indicates a liberal rather than monopolistic mobile phone market, a necessary ingredient for competition and growth of the mobile phone market and the larger ICT sector in Ghana for national development. 
Given that technology is very dynamic and mobile phone penetration and consumption continues to grow rapidly especially in Africa, there is an urgent need for manufacturers and retailers to understand those drivers of mobile phone brands in order to enhance the survival of their brands. In the midst of the proliferation of different mobile phone brands, understanding the target and potential niche markets such as tertiary students and their brand choices of mobile phone and those other sociodemographic factors that drives their brand choice will enable manufacturers to sustain their brands to increase profitability. The study considers tertiary students as prospective long-term users of ICT particularly mobile phones for academic work and many other socio-economic activities. The choice of students as subjects for this study could not have been any better since Dadzie and BoachieMensah (2011) reported that tertiary students dominate the Ghanaian mobile phone users. Even though, the study could not cover all tertiary students in Ghana, the choice of subjects from a private, a public and a polytechnic could as well serve as a proxy for all tertiary students in Ghana. Thus, the generalization of the findings could be extended to all tertiary students in Ghana, albeit with caution.

The drawback of the study could be that only univariate and bivariate analyses of the variables were undertaken. It is possible that multivariate analysis of the interactive effects of the independent variables would generate further insights. Another shortfall of this study is the rather limited nature of the sample to only tertiary students in Ghana. A wider mixed of mobile phones users with wider personal characteristics used by Dadzie and Boachie-Mensah (2011), Boateng and Quansah (2013) and Yaşa and Bozyiğit (2012), would have enriched the outcomes of this study. These, notwithstanding, the conclusions are still valid within the context of tertiary students who represent the youth and presumably active users of mobile phones.

\section{Implications}

This study has key implications for marketers of ICT products and mobile phone manufacturers.

- Manufacturers should continue to improve on the quality of their mobile phones particularly its durability in order to sustain their consumers.

- There was evidence to suggest that most mobile phone brands did not promote their products in Ghana. Thus, retailers and manufacturers must vigorously promote their brands through adverts and special discounts for students in order to attract and sustain their consumers.

- Also, mobile phone manufacturers and retailers could enter into strategic alliances or partnerships with tertiary institutions in Ghana to access the huge potential markets that tertiary students in Ghana offers.

\section{Acknowledgement}

The authors would like to thank the anonymous reviewers for constructive comments on earlier version of this paper.

\section{References}

Aaker, D. A. (1991). Managing brand equity. San Francisco: Free Press.

AMA (2003). Dictionary of marketing. Retrieved from http: //www.marketingpower.com/ live/mgdictionary-view329.php, American Marketing Association, Chicago, IL, (accessed 12 December 2013).

Ayanwale, A. B., Alimi, T. \& Ayanbimipe, M. A. (2005). The influence of advertising on consumer brand preference. Journal of Social Science, 10(1), 9-16.

Babbie, E. (1990). Survey research methods, $2^{\text {nd }}$ ed. Belmont, CA: Wadsworth Publishing Company 
Bateson, J.E.G. (1995). Managing services marketing texts and readings, $3^{\text {rd }}$ ed. Orlando, FL: The Dryden Press.

Bertilsson, J. (2009). The Way Brands Work; Consumers' understanding of the creation and usage of brands. Lund: Business Press.

Bitta, J. D. A. \& Monroe, K. B. (1974). The influence of adaptation level on subjective price perceptions. In S. Ward \& P. Wright, Advances in consumer research, Vol. 1, eds., (pp. 359-369), Association for Consumer Research.

Boateng, H. \& Quansah, M. (2013). Mobile telecommunication networks choice among Ghanaians. Management Science Letters, 3(7), 1839-1850.

Chan, A. K.K. \& Huang, Y.Y. (1997). Brand naming in China-a linguistic approach. Marketing Intelligence \& Planning, 15(5), 227-234.

Dadzie, A. \& Boachie-Mensah, F. (2011). Brand preference for mobile phone operator services in the Cape Coast Metropolis. International Journal of Business \& Management, 6(11), 190-205.

Datte'e, B. \& Weil, H.B. (2005). Dynamics of social factors in technological substitutions. Working Paper, No. 4599-05, Cambridge, MA: MIT Sloan School of Management.

De Chernatony, L. \& McDonald, M. (1998). Creating powerful brands in consumer service and industrial markets, $2^{\text {nd }}$ ed. Oxford: Butterworth-Heinemann.

Erdem, T., \& Swait, J. (1998). Brand equity as a signaling phenomenon. Journal of Consumer Psychology, 7(2), 131-157.

Ferraro, R., Bettman, J. R., \& Chartrand, T.L. (2009). The power of strangers: the effect of incidental consumer brand encounters on brand choice. Journal of Consumer Research, 35, 729-41.

Farquhar, P.H. (1989). Managing brand equity. Marketing Research, 1(3), 24-33.

Farquhar, P. H., Julia, Y. Han, Paul M. Herr \& Yuji, I. (1992). Strategies for leveraging master brands. Marketing Research, 4(3), 32-43.

Gabbott, M. \& Hogg, G. (1999). Consumer involvement in services: a replication and extension. Journal of Business Research, 46, 159-166.

Garvin, D. A. (1987). Competing on the eight dimensions of quality. Harvard Business Review, 65,101-109.

Gobe, M. (2001). Emotional branding: the new paradigm for connecting brands to people. New York: Allworth Press

Graeff, T.R. (1996). Using promotional messages to manage the effects of brand and self-image on brand evaluations. Journal of Consumer Marketing, 13(3), 4-18.

Hakoama, M. \& Hakoyama, S. (2012). The impact of cell phone use on social networking and development among college students. The AABSS Journal, 15, 1-20.

Hamann, D., Williams, R. \& Omar, M. (2007). Branding strategy and consumer high-technology product, The Journal of Product \& Brand Management, 16(2), 98 -111.

Hao, L., Gao C. \& Liu Z. (2007). Customer-based brand equity and improvement strategy for mobile phone brands: foreign versus local in the Chinese market. International Management Review, 3(3), 76-83.

Hood, D. \& Henderson, K. (2005). Branding in the United Kingdom public library service. New Library World, 106(2), $16-28$.

Hoyer, W. D. \& Brown, S. P (1990). Effects of brand awareness on choice for a common, repeat purchase product. Journal of Consumer Research, 17, 141-148.

In-Stat/MDR (2002). The worldwide PDA market: the next generation of mobile computing. Research Report. http://www.instat.com (Accessed December 2011).

Jiang, P. (2004). The role of brand name in customization decisions: a search vs. experience perspective. Journal of Product \& Brand Management, 13(2), 73-83.

Jones, S. (2002). 3G launch strategies, early adopters, why \& how to make them yours. Tarifica Report, (October).

Karjaluoto, H. Karvonen, J., Kesti, M., Koivumäki, T., Manninen, M., Pakola, J., Ristola, A. \& Salo, J. (2005). Factors affecting consumer choice of mobile phones: two studies from Finland. Journal of Euromarketing, 14(3), 59-82. 
Kay, M. J. (2006). Strong brands and corporate brands. European Journal of Marketing, 40(7/8), 742-60.

Keller, K. L. (2008). Strategic Brand management; Building, measuring and managing brand equity. New Jersey: Pearson Education, Inc.

Keller, K. L. (2003) Strategic Brand Management: Building, Measuring and Managing Brand Equity, $2^{\text {nd }}$ ed., Englewood Cliffs, NJ: Prentice-Hall.

Keller, K. L. (1993). Conceptualizing, measuring, and managing customer-based brand equity. Journal of Marketing, 57(1), 1-22.

Krishnamurthi, L. \& Raj, S. P. (1991). An empirical analysis of the relationship between brand loyalty and consumer price elasticity. Marketing Science, 10(2), 172-183.

Kotler, P., Asplund, C. Rein, I. \& Haider, D. (1999) Marketing Places Europe. London: Pearson Education Ltd.

Lassar, W., Mittal, B. \& Sharma, A. (1995). Measuring customer-based brand equity. Journal of Consumer Marketing, 12(4), 11-19.

Liu, C.M. (2002). The effects of promotional activities on brand decision in the cellular telephone industry. The Journal of Product \& Brand Management, 11(1), 42-51.

Marat, E. (2009). Branding in Central Asia: a new campaign to present ideas about the state and the nation', Europe-Asia Studies, 61, 1123-1135.

Macdonald, E. \& Sharp, B. (2000). Brand awareness effects on consumer decision making for a common, repeat purchase product: A replication. Journal of Business Research, 48(1), 5-15.

Narteh, B., Odoom, R., Braimah, M. \& Buame, S. (2012). Key drivers of automobile brand choice in sub-Saharan Africa: the case of Ghana', Journal of Product \& Brand Management, 21(7), 516528.

Nowlis, S. M. \& Simonson, I. (1997). Attribute-task compatibility as a determinant of consumer preference reversals. Journal of Marketing Research, 34, 205-218.

Petruzzellis, L. (2010). Mobile phone choice: technology versus Marketing: The brand effect in the Italian market. European Journal of Marketing, 44(5), 610-634

Pitta, D. A., \& Katsanis, L. P. (1995). Understanding brand equity for successful brand extension. Journal of Consumer Marketing, 12(4), 51 - 64.

Riquelme, H. (2001). Do consumers know what they want? Journal of Consumer Marketing, 18(5), 437-448.

Rossiter, J. R. \& Percy, L. (1987). Advertising and Promotion Management. Singapore: McGrawHill.

Rossiter, J. R., Percy, L. \& Donovan, R. J. (1991). A better advertising planning grid. Journal of Advertising Research, 31(5), 11-21.

Sethuraman, R. \& Cole, C. (1999). Factors influencing the price premiums that consumers pay for national brands over store brands. Journal of Product \& Brand Management, 8(4), 340 - 351.

Soomro, M. I., Jatoi, M. M. \& Gilal, R. G. (2011). Consumer brand choice in a no-brand awareness situation of low involvement Products. Interdisciplinary Journal of Contemporary Research in Business, 2(12), 392-404.

Steyn, B. \& Puth, G. (2000). Corporate communication strategy. South Africa: Sandown, Heinemann Publishers.

Temporal, P. \& Lee, K.C. (2001). Hi-tech hi-touch branding: creating brand power in the age of technology. New York, NY: John Wiley \& Sons.

Hoyer, W.D. \& Brown, S.P. (1990). Effects of brand awareness on choice for a common, repeat purchase product', Journal of Consumer Research, 17, 141-148.

Vanrenen, J. (2005). How to add value to your brand. Retrieved from http://www.sbcs.org.au/SBSC\%20Newsletter-December\%2011.pdf.

Walker, R. (2008) Buying in: the secret dialogue between what we buy and who we are. Georgia: Random House.

Wiedmann, K., Hennigs, N. \& Siebels, A. (2009). Value-based segmentation of luxury consumption behavior. Psychology \& Marketing, 26(7), 625-651. 
1814

Yaşa, E. \& Bozyiğit, S. (2012). Preference of consumers of Y generation by using mobile phone and GSM operators: a pilot study to determine the preferences of university students in Mersin. Cag University Journal of Social Sciences, 9(1), 29-46. 